\title{
The Application of Fiduciary Guarantee in the Perspective of Islamic Law
}

\section{Wieke Dewi Suryandari*)}

${ }^{*}$ ) Faculty of Law, Universitas Darul Ulum Islamic Center Sudirman GUPPI (UNDARIS), Email: wieke@undaris.ac.id

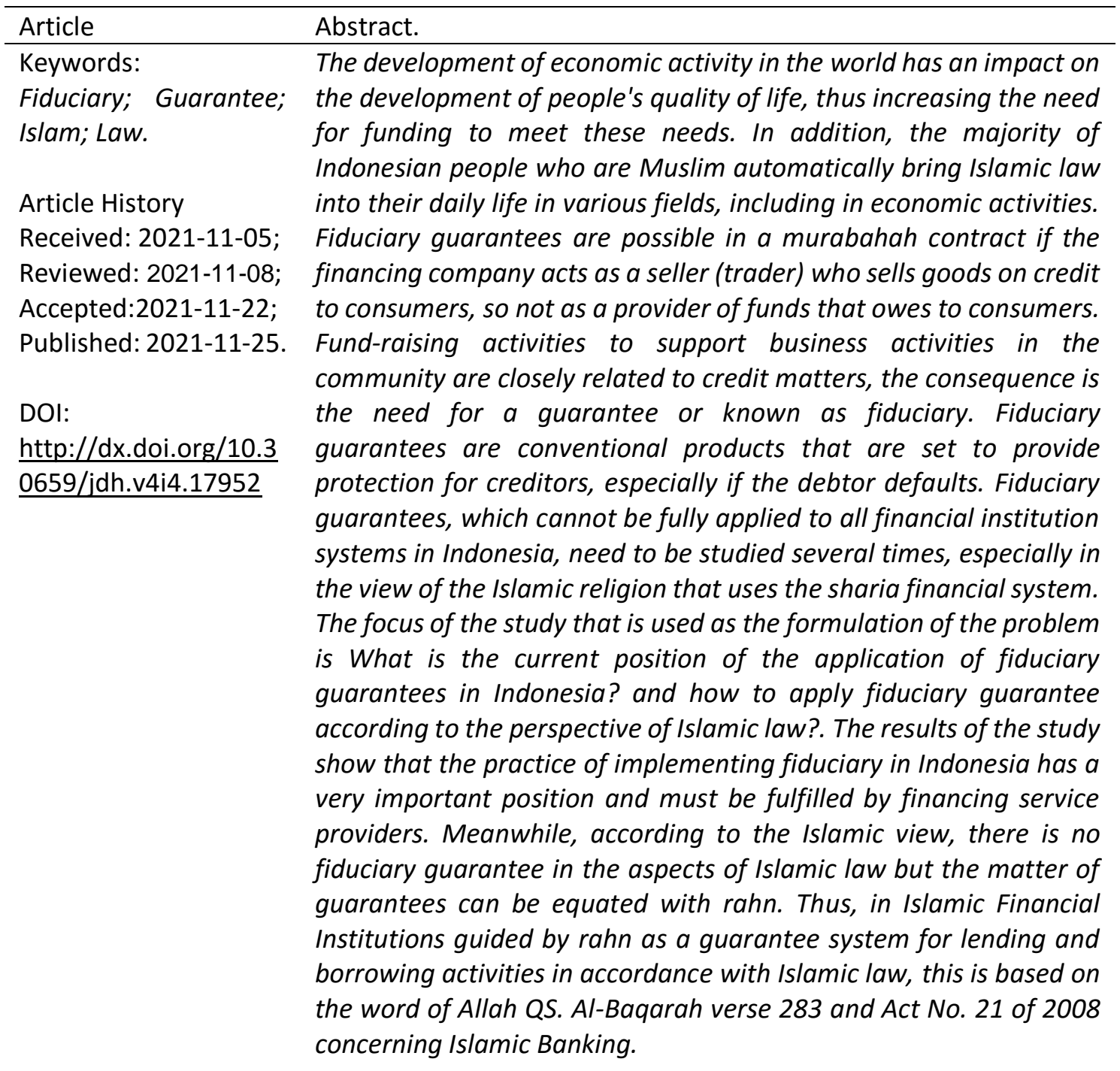

(C)2021; This is an Open Access Research distributed under the term of the Creative Commons Attribution License (https://Creativecommons.org/licences/by/4.0), which permits unrestricted use, distribution, and reproduction in any medium, provided the original works is properly cited

\section{Introduction}

Economic activity in the modern era as it is today shows a very rapid pace of development in all sectors of life. The development of this economic activity also has an impact on the development of the quality of life of the community, where there are other factors that influence the progress of science and technology, social and culture. 
Along with the development of the quality of life of the community, the human needs also increase to meet daily needs in the form of goods and services ${ }^{1}$.

Efforts to meet the growing needs of the community will also increase the need for funding to meet these needs. The desire of every community to improve their standard of living that is more prosperous, prosperous, fulfilled all their needs sometimes overrides the fact that to achieve this requires great economic capacity, especially in terms of finance or funding. , in economic activities carried out by the community Most of the funding sources come from lending and borrowing activities.

Fund-raising activities to support business activities in the community or just to fulfill needs are closely related to credit matters, especially for people who experience difficulties in working capital or other fairly large needs. The matter of borrowing and borrowing has now become a common activity in society. The community in general is aware of the terms and consequences of borrowing and lending activities, one of the main requirements is the existence of a guarantee. The form of guaranteeing goods to get funding or financing is through fiduciary guarantees.

Fiduciary guarantees in the form of financing products are currently growing rapidly in the midst of people's lives. In Article 1 paragraph (1) of Act No. 42 of 1999 concerning Fiduciary Guarantees, it is explained that fiduciary is the transfer of ownership rights to an object on the basis of trust provided that the object whose ownership rights are transferred remains in the control of the owner of the object.

Fiduciary guarantees are conventional products that are set to provide protection for creditors, especially if the debtor defaults. Creditors can execute fiduciary guarantees to debtors as a form of compensation in accordance with applicable law ${ }^{2}$. In banking transaction products, almost all of them apply a guarantee system. In financial institutions that use a conventional system based on debt, fiduciary guarantees can be applied. However, in Indonesia there are Islamic financial institutions whose transactions are not based on accounts payable, so fiduciary guarantees are not compatible with some banking models. ${ }^{3}$. The form of guarantee in Islam has similarities with fiduciary guarantees, although not absolutely the exact same, namely letter guarantees (al-rahn al-tafsili).

Fiduciary guarantees, which have not been fully implemented in all systems of financial institutions in Indonesia, need to be carried out several studies, especially in the view of the Islamic religion that uses the sharia financial system. It should be noted from an Islamic perspective that this guarantee is in accordance with the main points of Islamic religious teachings as contained in the Qur'an, Hadith and the opinions of scholars or not yet fully appropriate in the application of fiduciary guarantees for the benefit of both parties involved.

\footnotetext{
${ }^{1}$ A Chuasanga, Ong Argo Victoria. (2019). Legal Principles Under Criminal Law in Indonesia and Thailand, Jurnal Daulat Hukum, Vol 2, No 1 (2019) http://jurnal.unissula.ac.id/index.php/RH/article/view/4218

${ }^{2}$ Muhammad Maksum. "Penerapan Hukum Jaminan Fidusia dalam Kontrak Pembiayaan Syari'ah" Jurnal $\begin{array}{lllllll}\text { Cita Hukum } & \text { Vol.3 } & \text { No.1 } & \text { (2015) } & \text { p. } & 2 & \text { url: }\end{array}$ http://journal.uinjkt.ac.id/index.php/citahukum/article/view/1837/pdf

${ }^{3}$ Muhammad Sabir and Rifka Tunnisa. "Jaminan Fidusia dalam Transaksi Perbankan (Studi Komparatif Hukum Positif dan Hukum Islam)". Mazahibuna: Jurnal Perbandingan Mazhab Vol. 2 No.1 (2020) p. 80 url: http://journal.uin-alauddin.ac.id/index.php/mjpm/article/view/14284
} 


\section{Research Methods}

This research uses a normative juridical research method using normative case studies in the form of products of legal behavior, for example in reviewing laws. The subject of the study is the law which is conceptualized as a norm or rule that applies in society and becomes a reference for everyone's behavior. So that normative legal research focuses on an inventory of positive law, legal principles and doctrines, legal findings in cases in concreto, legal systems, synchronization levels, legal comparisons and legal history. The use of normative juridical research methods, according to Johnny Ibrahim $^{4}$, has the advantage of having the ability to use various models of research approaches in addition to the approaches commonly used in the normative juridical method, namely the conceptual approach, the law approach and the case approach.

Therefore, this study uses a critical discourse analysis approach using abductive reasoning in order to obtain and find intersubjective truths. The type of data used in this research is secondary data, which consists of primary legal materials, secondary legal materials and tertiary legal materials obtained through library research.

\section{Results and Discussion}

\subsection{Position of Application of Fiduciary Guarantee in Indonesia}

The State of Indonesia is a state of law, as stated in the 1945 Constitution Article 1 Paragraph (3) which states that "the State of Indonesia is a state of law". This makes the position of the Indonesian state which in the entire order of social, national and state life must be based on all applicable legal regulations ${ }^{5}$. In accordance with one definition of the rule of law, where every act of state administration must be carried out within the corridor of law, those who must guard the law are all state administrators and all citizens by exercising their constitutional rights and obligations. ${ }^{6}$. The law that applies in Indonesia is coercive and binds all elements of social life to be able to live with high legal compliance, including in accommodating economic activities ${ }^{7}$.

Borrowing and lending activities or financing credit in practice are closely related to the existence of a guarantee, where the meaning of this guarantee is a special guarantee and not a general guarantee as regulated in article 1131 of the Civil Code. Banks are prohibited from giving credit to any party without a sufficient guarantee. In banking, in order to secure the credit provided, collateral is considered a powerful tool, and the bank as a creditor must always be guided by the Commaditerings Verbood

\footnotetext{
4Johnny Ibrahim. 2012. Teori dan Metodologi Penelitian. Bayumedia Publishing. Jakarta. p. 300

${ }^{5}$ Muhammad Zainuddin dan Nurul Nisah. "Peningkatan Sadar Hukum Berbangsa Dan Bernegara Ditinjau Dari Ajaran Ahlusunah Wal Jama'ah". Jurnal lus Constituendum Vol. 6 No.1 (2021) p. 57 url: https://journals.usm.ac.id/index.php/jic/article/view/2146

${ }^{6}$ Atang Hermawan Usman. "Kesadaran Hukum Masyarakat dan Pemerintah Sebagai Faktor Tegaknya Negara Hukum di Indonesia". Jurnal Wawasan Hukum Vol. 30 No.1 (2014) p. 27 url: http://ejournal.sthb.ac.id/index.php/jwy/article/view/74

${ }^{7}$ Ong Argo Victoria, Ade Riusma Ariyana, Devina Arifani. (2020). Code of Ethics and Position of Notary in Indonesia. Sultan Agung Notary Law Review 2 (4), 397-407, http://lppmunissula.com/jurnal.unissula.ac.id/index.php/SANLaR/article/view/13536
} 
principle which means that the bank does not want to bear the business risk of the debtor with the credit that has been given. ${ }^{8}$

The concept of guarantees in lending and borrowing activities is then known as fiduciary guarantees. The term fiduciary is an official term and has long been known in Indonesian law. Fiduciary in Indonesian is called the surrender of property rights in trust $^{9}$.

Fiduciary itself comes from the word "fides" which means trust. Meanwhile, in Dutch terminology, fiduciaries are often referred to as fiduciary eigendom overdracht, namely the transfer of property rights on the basis of trust, meaning the ownership rights of the debtor's goods are used as collateral to creditors based on trust alone, while physically the goods in question remain in the possession of the debtor ${ }^{10}$. There are two forms of fiduciary institutions, namely fiducia cum creditore and fiducia cum omico, and both arise from an agreement called pactum fiduciae which is then followed by the transfer of rights or in iure cessio which is carried out by means of constitutum possessorium (verklaring van houderschap). ${ }^{11}$ In Act No. 42 of 1999 Article 1 number (1) concerning Fiduciary Guarantees it is written that the definition of Fiduciary is "the transfer of ownership rights to an object on the basis of trust provided that the object whose ownership rights are transferred remains in the control of the owner of the object".

In addition to the notion of fiduciary, there is also the term fiduciary guarantee. The definition of Fiduciary Guarantee is contained in Article 1 paragraph (2) of Act No. 42 of 1999 concerning Fiduciary Guarantee, namely:

Fiduciary guarantees are security rights for movable objects, both tangible and intangible and immovable objects, especially buildings that cannot be encumbered with mortgage rights as referred to in Act No. 4 of 1996 concerning Mortgage Rights which remain in the control of the fiduciary giver, as collateral for the repayment of certain debts, which gives priority to the fiduciary recipient over other creditors".

In line with this understanding, it can be interpreted that material guarantees, both tangible and intangible movable objects given by the debtor to the creditor to guarantee the repayment of his debt, as well as the legal relationship between the debtor (fiduciary giver) and creditor (fiduciary recipient) is a legal relationship based on a belief. The fiduciary giver believes that the fiduciary recipient wants to return the ownership rights to the goods that have been given after the debt is paid off. Vice versa, the fiduciary recipient also believes that the fiduciary giver will not act to misuse the goods that are used as collateral while in his power ${ }^{12}$.

\footnotetext{
${ }^{8}$ Supianto, 2015, Hukum Jaminan Fidusia, Garudhawaca, Jember, p. 10-11

${ }^{9}$ Munir Fuady. 2013. Hukum Jaminan Utang. Erlangga. Jakarta, p. 101

${ }^{10}$ Adrian Sutedi. 2010. Hukum Hak Tanggungan. Sinar Grafika, Jakarta, p. 33

${ }^{11} Z a k k y$ Septian Irhami Maulana and Lathifah Hanim. "Eksekusi Jaminan Fidusia Menurut Undang-Undang Fidusia No. 42 Tahun 1999 (Studi di Kantor PT. Pegadaian Persero Cabang Pedurungan Kota Semarang)" Prosiding KONFERENSI ILMIAH MAHASISWA UNISSULA (KIMU) 4 (2020) p. 565 url: http://jurnal.unissula.ac.id/index.php/kimuh/article/view/11818/4797

12 Yaya Kareng, Ong Argo Victoria, R. Juli Moertiyono. (2019). How Notary's Service in Thailand. Sultan Agung Notary Law Review, 1 (1), 46-56, http://jurnal.unissula.ac.id/index.php/SANLaR/article/view/4435
} 
Fiduciary guarantee institutions have been known and established in Roman legal society ${ }^{13}$. The history of fiduciary arrangements in Indonesia begins with Act No. 4 of 1992 concerning Housing and Settlements, and Act No. 16 of 1985 concerning Flats. The law is not sufficient to accommodate the development of debts in society. The government then passed Act No. 42 of 1999 concerning Fiduciary Guarantees ${ }^{14}$.

Fiduciary guarantees were born as a form of solution to the weakness of pawn guarantees. If there is a weakness in the pledge, the object of the guarantee is in the hands of the pawnbroker. While the fiduciary guarantee is a debt guarantee that is material in nature which in principle provides movable goods as collateral.

The position of the application of fiduciary guarantees is clear, when examined in the development of jurisprudence and laws and regulations, along with the legal basis for the application of fiduciary ${ }^{15}$ :

- Arrest Hoge Raad 1929, dated January 25 on Beirbrouwerij Arrest (Netherlands),

- Arrest Hoggerechtshof, dated August 18, 1932 regarding BPM-Clynet Arrest (Indonesia), as well as

- Act No. 42 of 1999 concerning Fiduciary Security which consists of 8 chapters and 41 articles.

The subject of the fiduciary guarantee is the fiduciary giver and the fiduciary recipient, who acts as the fiduciary giver is the owner of the object that is the object of the fiduciary guarantee, while the fiduciary recipient is an individual or corporation that has receivables with payment guaranteed by a fiduciary. Based on Act No. 42 of 1999 concerning fiduciary guarantees, the objects of fiduciary security are divided into 2 types, namely movable objects, both tangible and intangible, and immovable objects, especially buildings that are not burdened with mortgage rights as related to flats as regulated in Act No. 16 of 1985 concerning Flats.

The nature of the fiduciary guarantee in its position is an accompanying agreement (accecoir) of a main agreement that creates obligations for all parties to fulfill an achievement. Fiduciary guarantees are imposed in the following ways: (a) Made with a notarial deed in Indonesian, (b) Debts whose settlement is guaranteed by fiduciary guarantees ${ }^{16}$.

It has been explained in Article 11 of Act No. 42 of 1999 concerning Fiduciary Guarantees, that objects located both inside and outside the territory of the Unitary State of the Republic of Indonesia that are burdened with fiduciary guarantees must be registered. Thus, this has clarified the position of the application of a valid fiduciary guarantee, and if there are other matters involving fiduciary execution, it will be followed up with a settlement based on the applicable laws and regulations.

\subsection{Application of Fiduciary Guarantee according to the Perspective of Islamic Law}

The concept of collateral in Islam has been known since the beginning of Islam, where the Prophet Muhammad himself had practiced debt guarantees with guarantees

\footnotetext{
${ }^{13}$ Muhammad Sabir and Rifka Tunnisa, Op. Cit, p. 82

${ }^{14}$ Muhammad Maksum, Op. Cit, p. 4

${ }^{15}$ Salim HS. 2014. Perkembangan Hukum Jaminan di Indonesia. Rajawali Pers. Jakarta p. 60

${ }^{16}$ Ibid., p. 65
} 
that could be in the form of people or objects. Collateral in the form of objects is called rahn, while guarantees in the form of people are called kafalah. Financially or institutionally, the bank guarantees the party who has applied for the loan service ${ }^{17}$.

In Islamic law the right of mortgage/collateral is known as Ar rahn (guaranteed goods), Ar rahn in the hands of al mutahin (the debtor) only functions as collateral for the debt of ar rahin (the debtor). The collateral can only be sold/appreciated if within a time agreed by both parties, the debt cannot be repaid by the person who owes it. Therefore, the rights of the creditor are only related to collateral, if the debtor is unable to pay off the debt ${ }^{18}$. The legal basis for borrowing and borrowing with collateral (rahn) is allowed and prescribed based on the Qur'an, As-Sunnah and ljma' of the scholars. The legal basis for rahn or pawning is stated in the word of Allah QS Al-Baqarah verse 283, as follows:

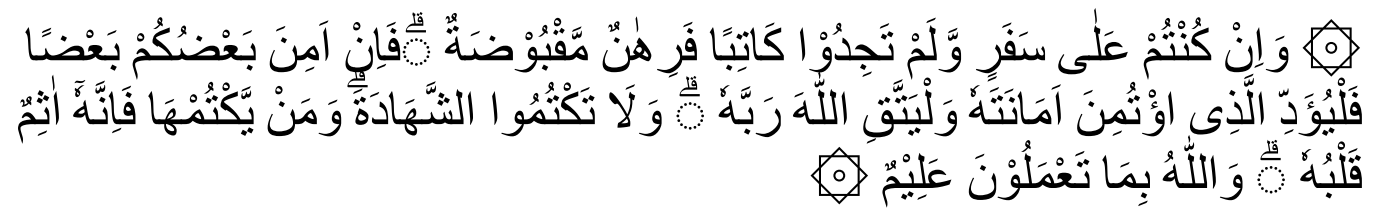

"And if you are on a journey and you do not find a writer, then let there be collateral to hold. However, if some of you believe in others, let the one who is trusted fulfill his mandate (debt) and let him fear Allah, his Lord. And do not hide the testimony, because whoever hides it, indeed, his heart is dirty (sinful). Allah is Knowing of what you do."

Linguistically, the word rahn means permanent, lasting and holding. Meanwhile, in terms, rahn is holding something in the right way with the aim of fulfilling obligations to pay debts to the debtor. As explained by Al-Subki from Syafi'iyah defines rahn, namely making an asset as a form of collateral for financing or loans, so that the financing or loan can be repaid with the value of the financing asset or guarantee that has been explained when the recipient of the fee or the borrower is unable to pay off the bonds. ${ }^{19}$. The concept of Islamic law does not recognize the term guarantee of property rights. But so far what has happened in the practice of Islamic banking, financing carried out by Islamic banks, one of which is also attached to a material guarantee under civil law. In formal juridical terms, the sharia-based financing activities do not conflict with the law. Problems in the context of sharia appear to look at sharia financing which is associated with the concept of fiduciary guarantees that are not known in the content of sharia economics ${ }^{20}$.

In practice, sharia financing still requires complementary components of sharia guarantees in order to obtain legal certainty. One of the legal products issued by DSN MUI in Fatwa No. 68/DSN-MUI/III/2008 concerning Rahn Tasjily has described the

\footnotetext{
${ }^{17}$ Muhammad Maksum, Op. Cit, p.5

${ }^{18}$ M. Yasir. "Aspek Hukum Jaminan Fidusia”. SALAM: Jurnal Sosial \& Budaya Syar'i Vol. 3 No. 1 (2016) hlm. 77 DOI: http://dx.doi.org/10.15408/sjsbs.v3i1.3307

${ }^{19}$ Sahib 'Abdullah Bashir Al-Shakhanabah. 2011. al-Djamanat al-'Ayniyah al-Rahn wamada Mashru'iyyatu Istithmariha fi al-Masarif al-Islamiyah. Dar al-Nafais. Yordania. p. 63-64

${ }^{20}$ Salim, Op. cit. p. 67
} 
concept of collateral with the transfer of ownership rights to goods as collateral as a form of sharia financial institution services to comply with Sharia principles. ${ }^{21}$

Rahn as collateral in the form of objects handed over on the principle of trust both physically and only the ownership rights from the debtor to the creditor for reasons of strengthening the certainty of timeliness and smoothness in the payment of debt belonging to the debtor (rahin) to the creditor (murtahin), which can be used as a substitute on the payment of debt if it is not paid rahin. The concept of rahn in Islam is applied in order to ensure and provide encouragement to debtors to pay off their debts in accordance with a predetermined period of time and avoid actions that can harm the party providing the debt. ${ }^{22}$.

Because fiduciary guarantees are not found in Islamic law, then in Islamic Economics the practice of rahn is carried out. As stated in Article 1 number 26 of Act No. 21 of 2008 concerning Islamic Banking which is called collateral, namely additional guarantees, both in the form of movable and immovable objects which are submitted by the owner of the collateral to a Sharia Bank or Sharia Business Unit to guarantee repayment obligations of the customer receiving the facility.

The ethics contained in Islamic banks as financial service ${ }^{23}$ providers with a money value system, as investors distribute funds through investment activities that are based on profit sharing, buying and selling systems, or renting. In addition, financial services are carried out according to the principles of wakalah (granting a mandate), kafalah (bank guarantee), hiwalah (debt transfer), rahn (debt guarantee or pawn), qard (policy lending for bailouts), and others. ${ }^{24}$.

There are several provisions on the practice of rahn in accordance with Islamic law, namely as follows:

- The customer submits a guarantee (marhun) to a Sharia bank (murtahin), this guarantee is in the form of movable goods;

- The payment contract is executed between rahin (customer) and murtahin (Sharia bank);

- After the financing contract is signed, and the collateral is received by the Islamic bank, the Islamic bank disburses the financing;

- Rahin make payments back plus the agreed fee. This fee is successful from the rent of the place and the cost for the maintenance of the collateral ${ }^{25}$.

\section{Conclusion}

Based on several descriptions of fiduciary, it can be concluded that in practice the

\footnotetext{
${ }^{21}$ Sutedi, Adrian. Op. cit. p. 44

${ }^{22}$ Riedel Wawointana. "Manfaat Jaminan Fidusia dalam Pelaksanaan Perjanjian Kredit Bank", Lex

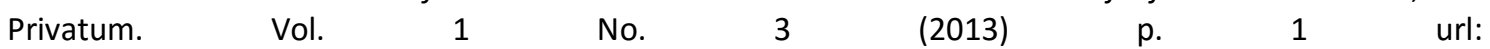
https://ejournal.unsrat.ac.id/index.php/lexprivatum/article/view/3041

${ }^{23}$ Deen, Thaufiq., Ong Argo Victoria \& Sumain. (2018). Public Notary Services In Malaysia. JURNAL AKTA: Vol. 5, No. 4, 1017-1026. Retrieved from http://jurnal.unissula.ac.id/index.php/akta/article/view/4135

${ }^{24}$ Nur Wahid. "Pelibatan Akad ljarah dalam Praktik Rahn di Bank Syari'ah Perspektif Hukum Ekonomi $\begin{array}{llllllll}\text { Syari'ah". Al-Manahij } & \text { Vol. } & 12 & \text { No.1 } & \text { (2018) } & \text { p. } & 153 & \text { url: }\end{array}$ http://www.ejournal.iainpurwokerto.ac.id/index.php/almanahij/article/view/1349e

${ }^{25}$ Imam Mustofa. 2016. Fiqh Muamalah Komputer. RajaGrafindo Persada. Jakarta. p. 202
} 
application of fiduciary in Indonesia has a very important position and must be fulfilled by financing service providers in accordance with Law no. 42 of 1999 concerning Fiduciary Guarantee. According to the Islamic view, there is no fiduciary guarantee in the aspect of Islamic law, but matters concerning guarantees can be equated with rahn. Thus, in Islamic Financial Institutions guided by rahn as a guarantee system for lending and borrowing activities in accordance with Islamic law, this is based on the word of Allah QS. Al-Baqarah verse 283 and Act No. 21 of 2008 concerning Islamic Banking.

\section{References}

\section{Journals:}

[1] A Chuasanga, Ong Argo Victoria. (2019). Legal Principles Under Criminal Law in Indonesia and Thailand, Jurnal Daulat Hukum, Vol 2, No 1 (2019) http://jurnal.unissula.ac.id/index.php/RH/article/view/4218

[2] Deen, Thaufiq., Ong Argo Victoria \& Sumain. (2018). Public Notary Services In Malaysia. JURNAL AKTA: Vol. 5, No. 4, 1017-1026. Retrieved from http://jurnal.unissula.ac.id/index.php/akta/article/view/4135

[3] Maksum, Muhammad. 2015. "Penerapan Hukum Jaminan Fidusia dalam Kontrak Pembiayaan Syari'ah" Jurnal Cita Hukum Vol.3 No.1 url: http://journal.uinjkt.ac.id/index.php/citahukum/article/view/1837/pdf

[4] Maulana, Zakky Septian Irhami dan Lathifah Hanim. 2020. "Eksekusi Jaminan Fidusia Menurut Undang-Undang Fidusia No. 42 Tahun 1999 (Studi di Kantor PT. Pegadaian Persero Cabang Pedurungan Kota Semarang)" Prosiding KONFERENSI $\begin{array}{lllll}\text { ILMIAH MAHASISWA UNISSULA } & \text { (KIMU) }\end{array}$ http://jurnal.unissula.ac.id/index.php/kimuh/article/view/11818/4797

[5] Ong Argo Victoria, Ade Riusma Ariyana, Devina Arifani. (2020). Code of Ethics and Position of Notary in Indonesia. Sultan Agung Notary Law Review 2 (4), 397-407, http://Ippm-unissula.com/jurnal.unissula.ac.id/index.php/SANLaR/article/view/13536

[6] Sabir, Muhammad dan Rifka Tunnisa. 2020. "Jaminan Fidusia dalam Transaksi Perbankan (Studi Komparatif Hukum Positif dan Hukum Islam) Mazahibuna: Jurnal Perbandingan Mazhab Vo. 2 No.1 url: http://journal.uinalauddin.ac.id/index.php/mipm/article/view/14284

[7] Usman, Atang Hermawan. 2014. "Kesadaran Hukum Masyarakat dan Pemerintah Sebagai Faktor Tegaknya Negara Hukum di Indonesia", Jurnal Wawasan Hukum Vol. 30 No.1 url: http://ejournal.sthb.ac.id/index.php/jwy/article/view/74

[8] Wahid, Nur. 2018. "Pelibatan Akad ljarah dalam Praktik Rahn di Bank Syari'ah Perspektif Hukum Ekonomi Syari'ah", Al-Manahij Vol. 12 No.1 (2018) hlm. 153 url: http://www.ejournal.iainpurwokerto.ac.id/index.php/almanahij/article/view/13 $\underline{49 \mathrm{e}}$

[9] Wawointana, Riedel. 2013. "Manfaat Jaminan Fidusia dalam Pelaksanaan Perjanjian Kredit Bank", Lex Privatum. Vol. 1 No. 3 url: https://ejournal.unsrat.ac.id/index.php/lexprivatum/article/view/3041

[10] Yasir, M. 2016. "Aspek Hukum Jaminan Fidusia" SALAM: Jurnal Sosial \& Budaya Syar'I Vo. 3 No. 1 DOI: http://dx.doi.org/10.15408/sjsbs.v3i1.3307 
[11] Yaya Kareng, Ong Argo Victoria, R. Juli Moertiyono. (2019). How Notary's Service in Thailand. Sultan Agung Notary Law Review, 1 (1), 46-56, http://jurnal.unissula.ac.id/index.php/SANLaR/article/view/4435

[12] Zainuddin, Muhammad dan Nurul Nisah. 2021. "Peningkatan Sadar Hukum Berbangsa Dan Bernegara Ditinjau Dari Ajaran Ahlusunah Wal Jama'ah," Jurnal $\begin{array}{lllll}\text { lus Constituendum } & \text { Vol. } & 6 & \text { No.1 }\end{array}$ https://journals.usm.ac.id/index.php/iic/article/view/2146

\section{Books:}

[1] Al-Shakhanabah, Sahib 'Abdullah Bashir. 2011. al-Damanat al-'Ayniyah al-Rahn wamada Mashru'iyyatu Istithmariha fi al-Masarif al-Islamiyah. Yordania: Dar alNafais

[2] Fuady, Munir. 2013. Hukum Jaminan Utang. Jakarta: Erlangga

[3] Ibrahim, Johnny. 2012. Teori dan Metodologi Penelitian. Jakarta: Bayumedia Publishing

[4] Mustofa, Imam. 2016. Fiqh Muamalah Komputer. Jakarta : RajaGrafindo Persada

[5] Salim, HS. 2014. Perkembangan Hukum Jaminan di Indonesia. Jakarta: Rajawali Pers

[6] Supianto. 2015. Hukum Jaminan Fidusia. Jembee: Garudhawaca

[7] Sutedi, Adrian. 2010. Hukum Hak Tanggungan. Jakarta: Sinar Grafika

[8] Sutedi, Adrian. 2011. Hukum Gadai Syariah. Bandung: Alfabeta

\section{Regulation:}

[1] Act No. 42 of 1999 concerning Fiduciary Guarantees, Supplement to the State Gazette of the Republic of Indonesia Number 3889

[2] Act No. 21 of 2008 concerning Sharia Banking, Supplement to the State Gazette of the Republic of Indonesia Number 4867 